\title{
Estimation of the Minimum Number of Replication Origins Per Chromosome in any Organism
}

Marcelo S. da Silva ${ }^{1,2, *}$

${ }^{1}$ Cell Cycle Laboratory, Center of Toxins, Immune Response and Cell Signaling (CeTICS), Butantan Institute, São Paulo, Brazil; '2Department of Chemical and Biological Sciences, Biosciences Institute, São Paulo State University (UNESP), Botucatu, São Paulo, Brazil

*For correspondence: marcelo.santos-silva@unesp.br

[Abstract] Eukaryote nuclear genomes predominantly replicate through multiple replication origins. The number of replication origins activated per chromosome during the S-phase duration may vary according to many factors, but the predominant one is replication stress. Several studies have applied different approaches to estimate the number and map the positions of the replication origins in various organisms. However, without a parameter to restrict the minimum of necessary origins, less sensitive techniques may suggest conflicting results. The estimation of the minimum number of replication origins (MO) per chromosome is an innovative method that allows the establishment of a threshold, which serves as a parameter for genomic approaches that map origins. For this, the MO can be easily obtained through a formula that requires as parameters: chromosome size, S-phase duration, and replication rate. The chromosome size for any organism can be acquired in genomic databanks (such as NCBI), the S-phase duration can be estimated by monitoring DNA replication, and the replication rate is obtained through the DNA combing approach. The estimation of $\mathrm{MO}$ is a simple, quick, and easy method that provides a new methodological framework to assist studies of mapping replication origins in any organism.

Keywords: DNA replication, Replication origins, Replication rate, S-phase duration, Chromosome size

[Background] For all living organisms, DNA replication is a key and highly regulated process of paramount importance for biological inheritance. The first step of DNA replication is the establishment of the genomic loci, where DNA synthesis begins. These loci are called replication origins (or just origins) (Méchali, 2010). In general, the beginning of DNA synthesis occurs after an initiator binds to an origin and recruits specific proteins that will result in the formation of the replisome in a process called origin firing. Each origin fired generates two replication forks that move in opposite directions. Replication forks synthesize DNA at a velocity (rate) that varies according to the organism and cell lineage (Myllykallio et al., 2000; Stanojcic et al., 2016; da Silva et al., 2017). The time needed for all chromosomes to replicate determines the S-phase duration, which seems to be robust for certain cell types and organisms (Zhang et al., 2017; da Silva et al., 2020).

Although prokaryotes from the Bacteria domain usually replicate their genome using only one origin, the vast majority of organisms (Archaea and Eukarya domains, in general) replicate their chromosomes from multiple origins (Leonard and Méchali, 2013). However, the exact number of origins fired per chromosome can vary according to cell type and the cellular environment (da Silva et al., 2020). In a recent study (da Silva et al., 2019), I developed a formula capable of estimating the minimum number 
Please cite this article as: da Silva, (2020). Estimation of the Minimum Number of Replication Origins Per Chromosome in any Organism,Bio-protocol 10

of origins $(\mathrm{MO})$ required to duplicate an entire chromosome within the S-phase duration. The principle of the formula is the bidirectional movement of the replication forks. Moreover, the S-phase duration, the size of the chromosome in question, and the average replication rate are required as parameters of the equation.

The estimation of MO per chromosome is an innovative method that allows the establishment of a threshold, which serves as a parameter to assist (or validate) genomic approaches that map origins, such as marker frequency analysis coupled to next-generation sequencing (MFA-seq), small leading nascent strand purification coupled to next-generation sequencing (SNS-seq), DNA microarray, and DNA combing. Under standard conditions, MO values show minimal variation since the variables used in the formula are, in general, stable. The MO formula is universal and can be applied for any organism, even procaryotes. In the analyzes presented here, the trypanosomatid parasite Trypanosoma brucei was used as a model. In this organism, the protocol typically takes 2-3 days from the estimation of the variables to results. However, if the necessary variables are available (i.e., they can be obtained from other studies), the estimation of MO per chromosome can be carried out immediately.

\section{Materials and Reagents}

1. Microtubes $1.5 \mathrm{ml}$ (Axygen, Maxyclear, catalog number: MCT-150-C-S)

2. Centrifuge tubes $15 \mathrm{ml}$ (Corning, catalog number: CLS430791)

3. Culture flasks $25 \mathrm{~cm}^{2}$ (Corning, canted neck, cap plug seal, catalog number: CLS430168)

4. Syringe filter $0.22 \mu \mathrm{m}$ (Sartori, Minisart Syringe filter, catalog number: 16534)

5. Micropipette tips (Axygen, $10 \mu \mathrm{l}, 200 \mu \mathrm{l}$ and 1,000 $\mu \mathrm{l}$ )

6. Serological pipettes (Costar Sterile, $10 \mathrm{ml}$ )

7. Microscope Slides (Knitell glass, non-color)

8. Coverslips (Knitell glass, $22 \times 22 \mathrm{~mm}$ )

9. Combicoverslips (Genomic vision, catalog number: COV-002-RUO)

10. Reusable plug modes (from Molecular combing system-Genomic vision)

11. 6-well flat-bottom plate (Costar, catalog number: 38015)

12. Plastic coverslips (use a cut plastic pocket for binder)

13. Nail varnish (any brand, preferably colorless)

14. Click-iT EdU Cell Proliferation Kit, Alexa Fluor 488 dye (ThermoFisher Scientific, catalog number: C10337)

15. 5'-lodo-2'-deoxyuridine (IdU) (Sigma-Aldrich, catalog number: 17125)

16. 5'-Chloro-2'-deoxyuridine (CldU) (Abcam, catalog number: ab213715)

17. Mouse $\alpha-B r d U / \alpha-I d U$ monoclonal antibody (BD, catalog number: 347580 )

18. Rat $\alpha-B r d U / \alpha-C l d U$ monoclonal antibody (Accurate, catalog number: YSRTMCA2060GA)

19. Goat $\alpha$-mouse IgG1 secondary antibody, Alexa Fluor 568 (ThermoFisher Scientific, catalog number: A-21124) 
20. Goat $\alpha-$ rat $\lg G(H+L)$ secondary antibody, Alexa Fluor 488 (ThermoFisher Scientific, catalog number: A-11006)

21. Paraformaldehyde (Sigma-Aldrich, catalog number: 158127)

22. Poly-L-lysine hydrochloride (Sigma-Aldrich, catalog number: P2658)

23. Bovine serum albumin (Sigma-Aldrich, catalog number: 05470)

24. Triton X-100 (Sigma-Aldrich, catalog number: T8787)

25. $\mathrm{NaCl}$ (Sigma-Aldrich, catalog number: S9888)

26. $\mathrm{Na}_{2} \mathrm{HPO}_{4}$ (Sigma Aldrich, catalog number: 255793)

27. Ethanol absolute (Merck Millipore, catalog number: 100983)

28. Vectashield Mounting Medium with DAPI (Vector Labs, catalog number: $\mathrm{H}-1200$ )

29. ProLong Gold Antifade Mountant (Thermo Fisher Scientific, catalog number: P36930)

30. Hydrochloric acid fuming $37 \%$ (Merck, catalog number: 100317)

31. Sodium hydroxide (Sigma-Aldrich, catalog number: 221465)

32. SDM-79 medium (LGC Biotecnologia, catalog number: BR30079-05)

33. Hemin (Merck, catalog number: H9039)

34. $\mathrm{KCl}$ (for molecular biology, any brand)

35. $\mathrm{KH}_{2} \mathrm{PO}_{4}$ (for molecular biology, any brand)

36. Fetal Bovine Serum (FBS) (Sigma-Aldrich, catalog number: F7524)

37. Streptomycin sulfate salt (Sigma-Aldrich, catalog number: S6501)

38. Penicillin $G$ sodium salt (Sigma-Aldrich, catalog number: P3032)

39. EDTA $2 \mathrm{H}_{2} \mathrm{O}$ (Ethylenediaminetetraacetic acid disodium salt dihydrate) (Sigma-Aldrich, catalog number: E5134)

40. $\mathrm{NaOH}$ (ACS reagent, any brand)

41. Ethanol (Absolute, Merck, catalog number: 100983)

42. N-Laurylsarcosine sodium salt (Sigma-Aldrich, catalog number: L5125)

43. Proteinase $K$ (ThermoFischer Scientific, catalog number: AM2544)

44. Anti-DNA Antibody, single stranded (mouse anti-ssDNA) (Millipore, catalog number: MAB3868)

45. Goat anti-Mouse IgG2b Cross-Adsorbed Secondary Antibody, Alexa Fluor 350 (anti-mouse Alexa Fluor 350) (ThermoFischer Scientific, catalog number: A-21140)

46. MES, free acid (ULTROL grade, Calbiochem, catalog number: 475893)

47. Phosphate buffered saline (1x PBS) (see Recipes)

48. Hemin Solution (HS) (see Recipes)

49. SDM-79 medium (for cultivate $T$. brucei procyclic cells) (see Recipes)

50. 5'-chloro-2'-deoxyuridine solution (CldU-S) (see Recipes)

51. 5-ethynyl-2'-deoxyuridine solution (EdU-S) (see Recipes)

52. 5'-iodo-2'-deoxyuridine solution (IdU-S) (see Recipes)

53. 0.5 M EDTA (see Recipes)

54. 0.65 M EDTA (see Recipes)

55. 1.5 M Tris- $\mathrm{HCl}$ (see Recipes) 


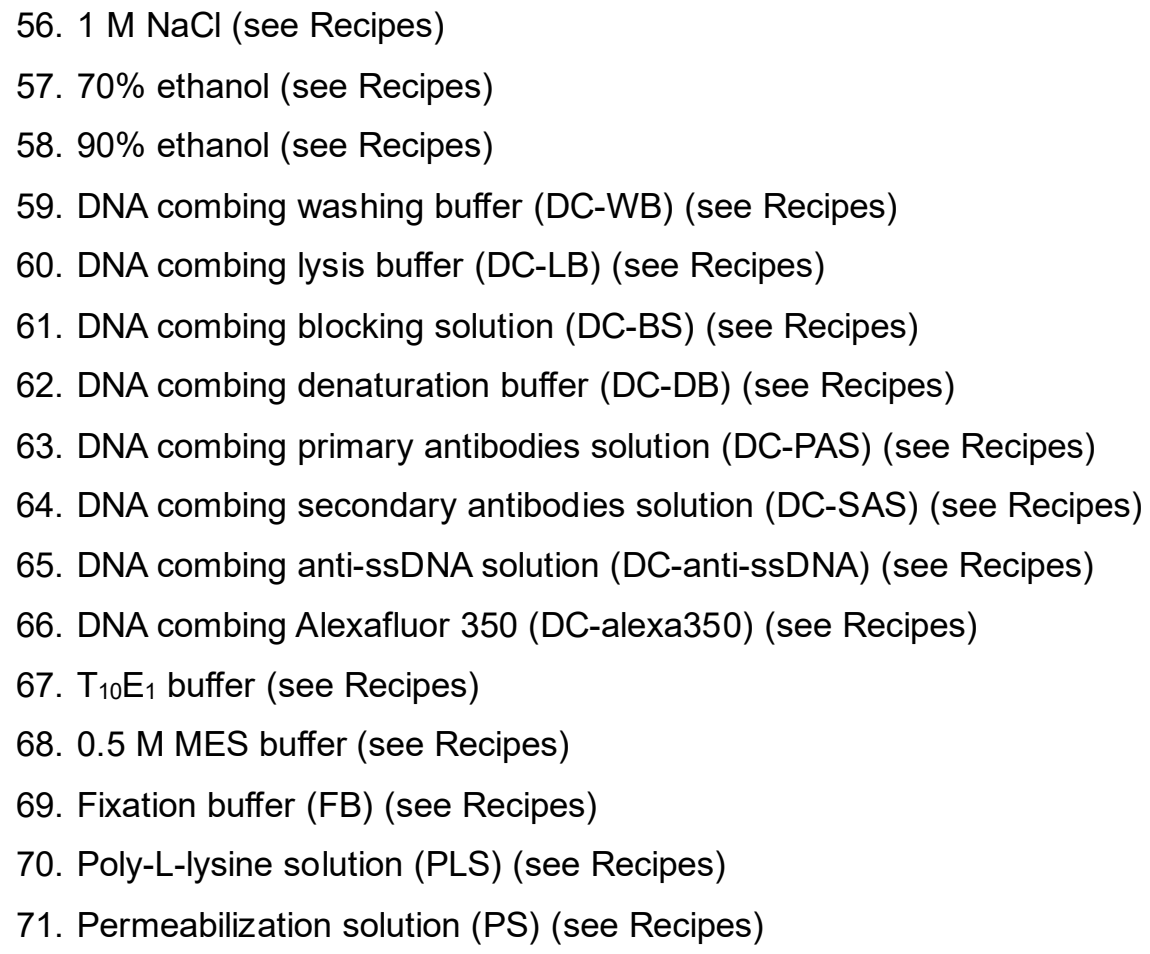

\section{Equipment}

1. Microcentrifuge (Eppendorf, model: $5424 \mathrm{R}$ )

2. Motorized pipet dispenser (Fisher Scientific, Fisherbrand, catalog number: 03-692-172)

3. Water bath (Cientec, model: CT-226)

4. Magnetic stirrer (Fisatom, model: 753A)

5. Incubator BOD (Vitrex, model: NI1705)

6. Fluorescence Microscope [Olympus, model: BX51, coupled to an XM10 digital camera. Filters specifications: U-MWU2 (excitation $=330-385 \mathrm{~nm}$; emission $=420 \mathrm{~nm}$ ), U-MWIBA3 (excitation $=460-495 \mathrm{~nm}$; emission $=510-550 \mathrm{~nm})$, and U-MWG2 $($ excitation $=510-550 \mathrm{~nm}$; emission $=$ $590 \mathrm{~nm})]$

7. Micropipettes (Gilson, models: Pipetman P10, P20, P200, and P1000)

8. Centrifuge (Eppendorf, model: $5810 \mathrm{R}$ ), equipped with $4 \times 250 \mathrm{ml}$ Swing-Bucket Rotor

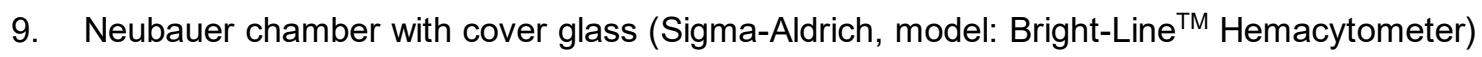

10. Biosafety Class II A2 cabinet (Pachane, model: PA 700)

11. $\mathrm{pH}$ meter (Gehaka, model: PG1800)

12. Autoclave (Tomy Seiko, model: SS-245)

13. FiberComb-Molecular combing system (Genomic Vision, model: MCS-001)

\section{Software}

1. CeCyD (Butantan Institute, published in da Silva et al., 2020, http://cecyd.vital.butantan.gov.br/) 
2. Doubling Time Calculator (2006) (version 3.1.0, https://doubling-time.com/compute more.php)

3. Olympus Cell F software (Olympus, version 5.1.2640)

4. Image $(\mathrm{NIH}$, version $1.47 \mathrm{t})$

5. Microsoft Excel (Microsoft Office-any version) or GraphPad Prism (GraphPad software, Inc.)

\section{Procedure}

Notes:

1. If you already have the values for chromosomes size, S-phase duration, and replication rate for the organism in question, the following steps $(A-C)$ are not necessary.

2. The description of the steps $B$ (estimation of the S-phase) and $C$ (estimation of the replication rate) uses as example the organism T. brucei. However, for other cell types these parameters can be found in specific studies when available [e.g., S. cerevisiae (Brewer et al., 1984; Sekedat et al., 2010; Ivanova et al., 2020); mammalian cells-MEFs cell (Ishida et al., 2001; Stanojcic et al., 2016; Pereira et al., 2017)].

A. Obtaining values for chromosome size

First option (for any organism):

1. Access the website https://www.ncbi.nlm.nih.gov/.

2. In 'popular resources' option (right side), click on genome.

3. Type the name of the organism of interest.

4. Obtain the values of chromosome size from the table.

Second option (only for trypanosomatids organisms):

1. Access the website https://tritrypdb.org/tritrypdb/.

2. In 'search for other data types' option (middle column), click on 'genomic sequences', then organism'.

3. Choose the organism of interest (e.g., Trypanosoma brucei).

5. Click on 'Get Answer'.

6. Obtain the values of chromosome size (length) from the table.

B. Estimation of the S-phase duration using CeCyD software

CeCyD is a user-friendly website able to calculate the values of cytokinesis (C), mitosis (M), G2, S, and $\mathrm{G} 1$ phases of the cell cycle, for any organism. For this, the user must enter the following parameters on the website: doubling time, percentage of cells in cytokinesis, percentage of cells in mitosis, minimum time to detect two EdU-labeled nuclei in the same cell, percentage of cells EdUlabeled after EdU pulse, and the duration of this EdU pulse. The following steps of this section describe how these parameters are obtained in T. brucei (used as an example). However, for other cell types, the S-phase duration can be obtained directly from specific studies when available [e.g., 
S. cerevisiae (Brewer et al., 1984; Ivanova et al., 2020); mammalian cells - MEFs cells (Ishida et al., 2001; Pereira et al., 2017)].

1. Prepare a set of $T$. brucei culture (here, it was used the procyclic forms) to estimate de doubling time. Initiates a growth curve with $1 \times 10^{6}$ cells $/ \mathrm{ml}$ at $28^{\circ} \mathrm{C}$ in $10 \mathrm{ml}$ of culture.

Note: The cell density for the beginning of the curve varies according to the cell type.

2. Harvest cell samples and count daily, until it reached the stationary phase.

3. Insert the values counted on https://doubling-time.com and take note of the doubling time value.

4. Prepare a new set of $T$. brucei culture (procyclic forms) to estimate the percentage of cells in mitosis and cytokinesis. Incubate cells $\left(28^{\circ} \mathrm{C}\right)$ until they reach exponential phase $\left(\sim 1 \times 10^{7}\right.$ cells/ml).

Note: The cell density for the exponential phase varies according to the cell type used.

5. Harvest $1 \mathrm{ml}$ of the culture by centrifugation at $800 \times g$ for $5 \mathrm{~min}$ at $4{ }^{\circ} \mathrm{C}$ and wash twice using $1 \mathrm{ml}$ of $1 \mathrm{x}$ PBS.

6. Remove the 1x PBS from cells carefully to preserve the pellet.

7. Suspend the pellet in $1 \mathrm{ml}$ of Fixation Buffer $(F B)$ and transfer to a $1.5 \mathrm{ml}$ microcentrifuge tube.

8. Incubate at $4{ }^{\circ} \mathrm{C}$ for $7 \mathrm{~min}$ and wash three times using $1 \mathrm{ml}$ of cold $1 \mathrm{x}$ PBS (centrifuging at $800 \mathrm{xg}$ for $5 \mathrm{~min}$ in each wash). For the last wash, suspend the pellet carefully into $500 \mu \mathrm{l}$ of $1 \mathrm{x}$ PBS. If the pellet is too small (i.e., almost invisible to the naked eye), decrease the volume to $100 \mu \mathrm{l}$ of $1 \mathrm{x}$ PBS.

9. Prepare the slides to receive the cells by spreading $2.5 \mu \mathrm{l}$ of Poly-L-lysine solution (PLS) onto slide surface until PLS dry out. Prepare three slides for each sample from Step B8.

Note: Use a coverslip to spread PLS onto slide (see da Silva et al., 2018 for more detail).

10. Spread the suspended-pellet (from Step B8) carefully in each of the three slides. Use 25-30 $\mu$ l and save the remaining suspended-pellet volume in case you need to remake some slides.

Notes:

a. Use the same surface where PLS was previous spread.

b. Each slide is one technical replicate.

11. Wait for the cells to precipitate and settle on slide for 10-15 min at room temperature. Ensure that the cells do not dry out.

12. Permeabilize the cells by adding $50 \mu \mathrm{l}$ of permeabilization solution (PS) for $10 \mathrm{~min}$ at room temperature.

13. Wash the slide containing cells three times using 1x PBS.

Note: Use a P1000 micropipette to spread (by sneezing) 1x PBS (1 ml) onto slide three times.

14. Ensure all the liquid was removed from the slide surface containing cells and add $4 \mu \mathrm{l}$ of Vectashield mounting medium containing DAPI.

Note: This reagent is used as anti-fade mounting solution and to stain organelles containing DNA. 
Please cite this article as: da Silva, (2020). Estimation of the Minimum Number of Replication Origins Per Chromosome in any Organism,Bio-protocol 10

15. Add a glass coverslip and seal using colorless nail varnish. Wait the varnish dry out for 5 min. The slide can be analyzed under a fluorescence microscope immediately or stored at $4{ }^{\circ} \mathrm{C}$ up to one month.

16. Count at least 100 cells and identify cells in mitosis (with the nucleus in division) and cytokinesis (with two separated nuclei in the same cell). Figure 1 shows representative images of T. brucei cells in mitosis (A) and cytokinesis (B).

Note: Capture images using the differential interference contrast (DIC) (if available) or phase contrast. Merge with DAPI to assist in the identification of cells in mitosis/cytokinesis.

Mitosis

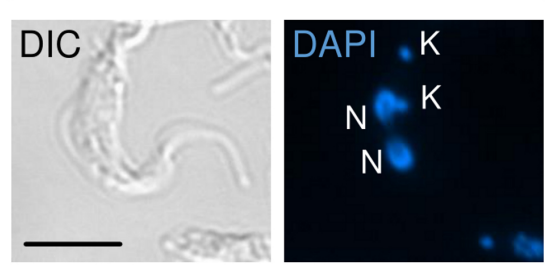

Cytokinesis

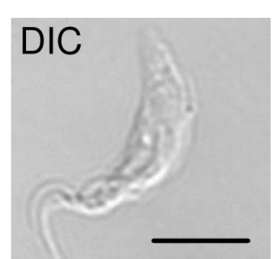

Figure 1. Representative images showing $T$. brucei cells in mitosis (left) and cytokinesis (right). It is worth to mentioning that in mitosis, the nucleus is dividing, while in cytokinesis the nucleus has already been divided. DIC was used to show the morphology of the cells, while DAPI was used to stain organelles containing DNA [nucleus $(\mathrm{N})$ and kinetoplast $(\mathrm{K})$ ]. Scale bars $=10 \mu \mathrm{m}$.

17. Take note the percentage of cells in mitosis and citokynesis.

18. Prepare a new set of $T$. brucei culture to estimate the minimum time to detect two EdU-labeled nuclei in the same cell. Incubate cells $\left(28^{\circ} \mathrm{C}\right)$ until they reach exponential phase $\left(\sim 1 \times 10^{7}\right.$ cells $/ \mathrm{ml})$.

Note: The cell density for the exponential phase varies according to the cell type used.

19. Add $100 \mu \mathrm{M}$ of 5-ethynyl-2'-deoxyuridine solution (EdU-S) in the culture containing T. brucei cells and wait for $30 \mathrm{~min}$.

20. Harvest $500 \mu \mathrm{l}$ of the culture by centrifugation ( $800 \times \mathrm{g}$ for 3 min at $4{ }^{\circ} \mathrm{C}$ ) and wash twice using $1 \mathrm{ml}$ of $1 \times$ PBS.

21. Follow the Steps B6-B7 exactly as previously described.

22. Incubate at $4{ }^{\circ} \mathrm{C}$.

23. Continue collecting samples every $15 \mathrm{~min}$ until reach $3 \mathrm{~h}$ of EdU incorporation ( 11 samples). Follow the Steps B20-B22 for each sample.

\section{Notes:}

a. Each sample should be incubated in FB for, at least, 7 min on ice.

b. At the end of this step, there should be 12 samples collected every $15 \mathrm{~min}$.

24. Take the 12 samples and wash three times each using $1 \mathrm{ml}$ of cold $1 x$ PBS (centrifuging at $800 \times g$ for $5 \mathrm{~min}$ in each wash). For the last wash, suspend the pellet of each sample carefully 
into $500 \mu \mathrm{l}$ of $1 \mathrm{x}$ PBS. If the pellet is too small (i.e., almost invisible to the naked eye), decrease the volume to $100 \mu \mathrm{l}$ of $1 \mathrm{x}$ PBS.

25. Prepare 12 slides by spreading $2.5 \mu$ of PLS onto slide surface until it dry out. Note: Use a coverslip to spread PLS onto slide. For more details, see da Silva et al. (2018).

26. Spread the suspended-pellets (from Step B23) carefully in each slide. Use 25-30 $\mu \mathrm{l}$ and save the remaining volume in case you need to remake some slides.

Note: Use the same surface where PLS was previous spread.

27. Wait for the cells to decant and settle on slide for 10-15 min at room temperature. Ensure that the cells do not dry out.

28. Permeabilize each sample by adding $50 \mu \mathrm{l}$ of PS for $10 \mathrm{~min}$ at room temperature.

29. Wash each slide containing cells three times using $1 x$ PBS.

Note: Use a P1000 micropipette to spread (by sneezing) 1x PBS (1 ml) onto slide three times.

30. Follow the protocol of Click-iT EdU Imaging Kit, established by the manufacturer.

Note: The protocol can be accessed here, on the topic Documents/Manuals and protocols: https://www.thermofisher.com/order/catalog/product/C10337\#/C10337.

31. At the end of the protocol established by the manufacturer, ensure all the liquid was removed from the slide surface containing cells and add $4 \mu \mathrm{l}$ of Vectashield mounting medium containing DAPI.

Note: This solution is used as the anti-fade mounting solution and to stain organelles containing DNA.

32. Add a glass coverslip and seal using colorless nail varnish. Wait the varnish dry out for $5 \mathrm{~min}$. The slide can be analyzed under a fluorescence microscope immediately or stored at $4{ }^{\circ} \mathrm{C}$ up to one month.

33. Search (in each sample) for a parasite containing two EdU-labeled nuclei in the same cell (i.e., cell in citokynesis). Start from the shortest time sample, i.e., $15 \mathrm{~min}$ after $30 \mathrm{~min}$ of EdU incorporation, and proceed with the other samples (i.e., $30 \mathrm{~min}$ after $30 \mathrm{~min}$ of EdU incorporation, $45 \mathrm{~min}$ after $30 \mathrm{~min}$ of EdU incorporation, etc.).

Note: For more details, see the description and images on Figure 1D from da Silva et al. (2019).

34. Once observed, take note the time required for this. This is the minimum time to detect two EdUlabeled nuclei in the same cell.

Note: The time obtained must be the sum of the initial time for EdU incorporation (30 min) plus the shortest time in which the two EdU-labeled nuclei were observed. In our case, this time was $2 \mathrm{~h}$. For details, see da Silva et al. (2019).

35. Prepare a new set of $T$. brucei culture to estimate the percentage of EdU-labeled cells during a EdU pulse. Incubate cells $\left(28^{\circ} \mathrm{C}\right)$ until they reach exponential phase $\left(\sim 1 \times 10^{7} \mathrm{cells} / \mathrm{ml}\right)$.

Note: The cell density for the exponential phase varies according to the cell type used.

36. Add $100 \mu \mathrm{M}$ of EdU-S in the culture containing T. brucei cells and wait for $1 \mathrm{~h}$. Note: This will be the duration of the EdU pulse, i.e., $1 \mathrm{~h}$. 
Please cite this article as: da Silva, (2020). Estimation of the Minimum Number of Replication Origins Per Chromosome in any Organism,Bio-protocol 10

37. Harvest $500 \mu \mathrm{l}$ of the culture by centrifugation ( $800 \times \mathrm{g}$ for $3 \mathrm{~min}$ at $\left.4^{\circ} \mathrm{C}\right)$ and wash twice using $1 \mathrm{ml}$ of $1 \mathrm{x}$ PBS.

38. Follow the Steps B6-B13 exactly as previously described.

39. Follow the protocol of Click-iT EdU Imaging Kit, established by the manufacturer.

Note: The protocol can be accessed here, on the topic Documents/Manuals and protocols: https://www. thermofisher.com/order/catalog/product/C10337\#/C10337.

40. At the end of the protocol established by the manufacturer, ensure all the liquid was removed from the slide surface containing cells and add $4 \mu \mathrm{l}$ of Vectashield mounting medium containing DAPI.

41. Add a glass coverslip and seal using colorless nail varnish. Wait the varnish dry out for $5 \mathrm{~min}$. The slide can be analyzed under a fluorescence microscope immediately or stored at $4{ }^{\circ} \mathrm{C}$ up to one month.

42. Count at least 100 cells (total) and identify cells EdU-labeled. Figure 2 shows representative images of T. brucei EdU-positive cells.

43. Measure the percentage of cells EdU-positive.

44. Once you have all the required parameters, access the CeCyD website: http://cecyd.vital.butantan.gov.br/, and input the values to obtain the duration of all the cell cycle phases. Take note of the S-phase duration.
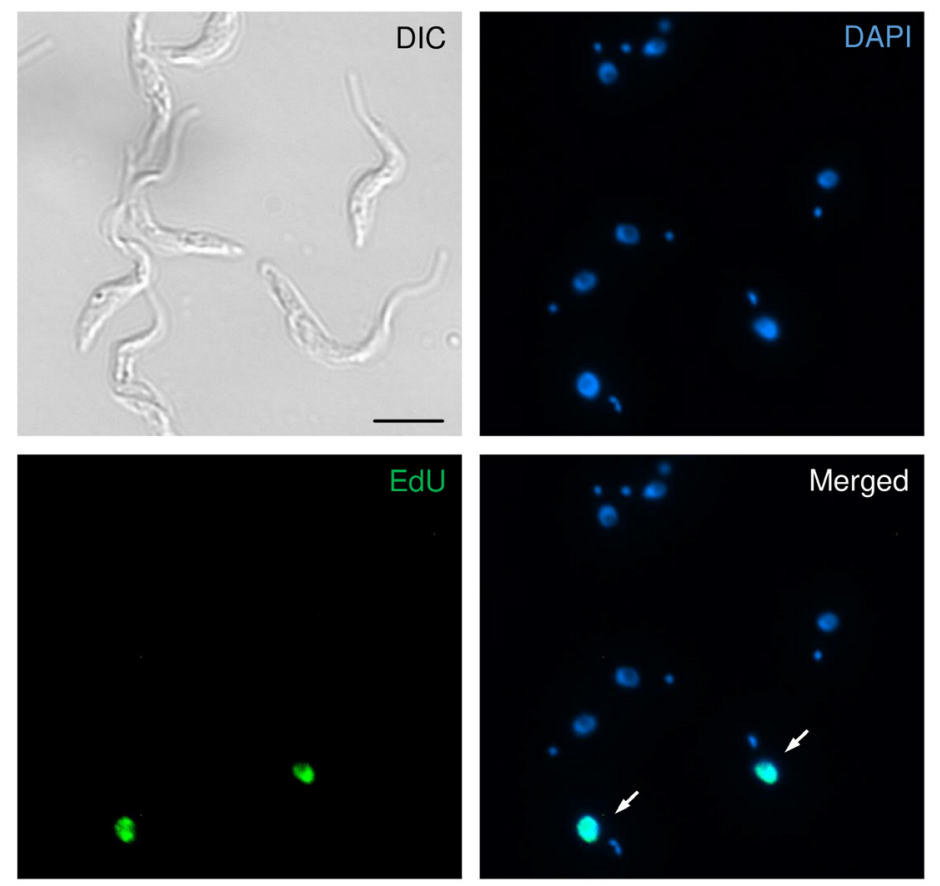

Figure 2. Representative image showing EdU-positive T. brucei cells. The representative image is organized in four squares: DIC (indicating the morphology of the cells), DAPI (staining organelles containing DNA), EdU (showing cells that uptaked EdU during the S-phase), and Merged (overlay between DAPI and EdU). The white arrows indicate EdU-positive cells. Scale bar $=10 \mu \mathrm{m}$. 


\section{Estimation of the replication rate using DNA combing}

The following steps of this section describe how the replication rate is obtained in T. brucei (used as an example). However, for other cell types, the replication rate can be obtained directly from specific studies when available [e.g., S. cerevisiae (Sekedat et al., 2010); mammalian cells-MEFs cells (Stanojcic et al., 2016)].

1. Prepare a set of T. brucei culture (here, it was used the procyclic forms) to perform the DNA combing assay. Initiates the culture with $2 \times 10^{6} \mathrm{cells} / \mathrm{ml}$ in $10 \mathrm{ml}$ of culture. Incubate at $28{ }^{\circ} \mathrm{C}$ for $24 \mathrm{~h}$. Count the cell density. The culture must be in the concentration of $\sim 1-2 \times 10^{7} \mathrm{cells} / \mathrm{ml}$, totalizing $\sim 1-2 \times 10^{8}$ cells.

Note: The cell density for the beginning of the DNA combing assay varies according to the cell type.

2. Add $300 \mu \mathrm{M}$ of $5^{\prime}$-iodo-2'-deoxyuridine solution (IdU-S) and wait for $30 \mathrm{~min}$.

3. Add $500 \mu \mathrm{M}$ of 5'-chloro-2'-deoxyuridine solution (CldU-S) and wait for $30 \mathrm{~min}$.

Note: Do not wash between the halogenated thymidine analogs (IdU and CldU) incorporation.

4. Harvest the whole culture by centrifugation $\left(1,600 \times g\right.$ for 3 min at $\left.4{ }^{\circ} \mathrm{C}\right)$ and wash twice using $1 \mathrm{ml}$ of $1 \mathrm{x}$ PBS. In the second wash, transfer the suspended-pellet to a $1.5 \mathrm{ml}$ microcentrifuge tube.

5. Wash using $500 \mu \mathrm{l}$ of DNA combing washing buffer (DC-WB) and suspend the pellet in $50 \mu \mathrm{l}$ of DC-WB. Keep at room temperature.

6. Prepare $2 \%$ agarose low-melting: Weigh $10 \mathrm{mg}$ of low melting agarose in a $1.5 \mathrm{ml}$ centrifuge tube. Using another $1.5 \mathrm{ml}$ centrifuge tube, heat $500 \mu \mathrm{l}$ of DC-WB (90 ${ }^{\circ} \mathrm{C}$ for $5 \mathrm{~min}$ ). Resuspend the $10 \mathrm{mg}$ of low melting agarose using the heated $500 \mu \mathrm{l}$ of DC-WB. Mix well to solubilize the agarose. Keep the solution heated at $65^{\circ} \mathrm{C}$.

7. Prepare the reusable plug modes to receive $100 \mu$ l of the agarose + cells mixture.

8. Gently mix $50 \mu \mathrm{l}$ of the agarose solution (from Step C6) in the $50 \mu \mathrm{l}$ of resuspended pellet (from Step C5), totalizing $100 \mu \mathrm{l}$. Add immediately to the previously prepared reusable plug model (from Step C7). Wait to cool and incubate at $4{ }^{\circ} \mathrm{C}$ for $1 \mathrm{~h}$.

9. Carefully unmold the plug in a $1.5 \mathrm{ml}$ epp containing $500 \mu \mathrm{l}$ of DNA combing lysis buffer (DCLB).

10. Incubate for $24 \mathrm{~h}$ at $50^{\circ} \mathrm{C}$.

11. Replace the DC-LB (gently) by a new one $(500 \mu \mathrm{l})$ and incubate for another $24 \mathrm{~h}$ at $50^{\circ} \mathrm{C}$.

12. Wash twice using $1 \mathrm{ml}$ of $\mathrm{T}_{10} \mathrm{E}_{1}$ buffer for $1 \mathrm{~h}$ (each wash) at room temperature.

13. Add $1 \mathrm{ml}$ of $\mathrm{T}_{10} \mathrm{E}_{1}$ buffer (gently) and incubate overnight at $4{ }^{\circ} \mathrm{C}$.

14. Discard the $\mathrm{T}_{10} \mathrm{E}_{1}$ buffer and incubate the plug in $800 \mu \mathrm{l}$ of $0.5 \mathrm{M} \mathrm{MES}, \mathrm{pH} 5.5$ at $68{ }^{\circ} \mathrm{C}$ for $20 \mathrm{~min}$. Next, remove the tube containing the plug from $68^{\circ} \mathrm{C}$ and incubate it immediately at $42{ }^{\circ} \mathrm{C}$ for $10 \mathrm{~min}$.

15. Add $2 \mu \mathrm{l}$ of $\beta$-agarase I $(1,000$ units $/ \mathrm{ml})$ and incubate overnight at $42{ }^{\circ} \mathrm{C}$. 
Note: In this step, add the $\beta$-agarase I in $200 \mu$ l of 0.5 M MES. Mix well and add it carefully in the plug dissolved with $800 \mu \mathrm{l} 0.5 \mathrm{M}$ MES.

16. Prepare the molecular combing system by adding $1 \mathrm{ml}$ of $0.5 \mathrm{M}$ MES into the reservoir of the FiberComb apparatus. Next, carefully pour the tube containing the plug dissolved (from Step C15) into the reservoir containing $1 \mathrm{ml}$ of $0.5 \mathrm{M}$ MES.

Note: At this stage, it is normal to form a viscosity in the liquid coming from the tube.

17. Immediately, place the Combicoverslip on the FiberComb apparatus and stretch the DNA according to equipments instructions.

Note: The solution containing the plug dissolved (i.e., incorporated DNA) inside the reservoir can be stored up to 1 week at $4{ }^{\circ} \mathrm{C}$ protected from light.

18. After stretch the DNA onto Combicoverslip, let it dry for a few seconds and incubate it at $65{ }^{\circ} \mathrm{C}$ for 2-4 h.

19. Place the Combicoverslip containing the DNA stretched in an appropriate container (e.g., use a 6-well flat-bottom plate). Carefully add $3 \mathrm{ml}$ of DNA combing denaturation buffer (DC-DB) and incubate for $20 \mathrm{~min}$.

20. Wash three times using $1 \mathrm{ml}$ of $1 \times$ PBS. Dehydrate the coverslip containing the DNA stretched successively using $2 \mathrm{ml}$ of: $70 \%$ ethanol, then $90 \%$ ethanol, and $100 \%$ ethanol (1 min each). Remove the alcohol and let the Combicoverslip dry completely at room temperature.

21. Block using $3 \mathrm{ml}$ of DNA combing blocking solution (DC-BS) for 20 min at $37^{\circ} \mathrm{C}$.

22. Prepare the DNA combing primary antibodies solution (DC-PAS).

Note: The DC-PAS must be freshly prepared, as it is for immediate use.

23. Add $20 \mu$ l of DC-PAS on the top of the Combicoverslip containing the DNA stretched (from Step C21). Cover with plastic coverslip. Incubate at $37^{\circ} \mathrm{C}$ for $1 \mathrm{~h}$ protected from light.

24. Wash twice using $1 \times$ PBS for 3 min each.

25. Prepare the DNA combing secondary antibodies solution (DC-SAS).

Note: The DC-SAS must be freshly prepared, as it is for immediate use.

26. Add $20 \mu$ l of DC-SAS on the top of the Combicoverslip containing the DNA stretched (from Step C24). Cover with a plastic coverslip. Incubate at $37^{\circ} \mathrm{C}$ for $1 \mathrm{~h}$ protected from light.

27. Wash twice using $1 \times$ PBS for 3 min each.

28. Prepare the DNA combing anti-ssDNA solution (DC-anti-ssDNA). Note: The DC-anti-ssDNA must be freshly prepared, as it is for immediate use.

29. Add $20 \mu$ l of DC-anti-ssDNA on the top of the coverslip containing the DNA stretched (from Step C27). Cover with plastic coverslip. Incubate at $37^{\circ} \mathrm{C}$ for $2 \mathrm{~h}$ protected from light.

30. Wash twice using $1 \times$ PBS for 3 min each.

31. Prepare the DNA combing Alexafluor 350 (DC-alexa350).

Note: The $D C$-alexa350 must be freshly prepared, as it is for immediate use.

32. Add $20 \mu \mathrm{l}$ of DC-alexa350 on the top of the coverslip containing the DNA stretched (from Step C30). Cover with plastic coverslip. Incubate at $37^{\circ} \mathrm{C}$ for $1 \mathrm{~h}$ protected from light.

33. Wash twice using $1 \times$ PBS for 3 min each. 
34. Ensure all the liquid was removed from the coverslip containing the DNA stretched. Mount the coverslip on a slide adding $20 \mu$ l of ProLong Gold antifade. Seal using colorless nail varnish and let dry for at least $1 \mathrm{~h}$ at room temperature.

35. Acquire images of DNA fibers using a fluorescence microscope. Merge acquired images using the Cell F Olympus or ImageJ software.

Notes:

a. The observation of longer DNA fibers requires the capture of adjacent fields.

b. The stretching factor along each molecule is contant $(1 \mu m=2 \mathrm{~kb})$.

c. Fibers $<100 \mathrm{~kb}$ must be excluded from the analysis to improve the accuracy of the assay.

d. Only green tracks (containing $\mathrm{CldU}$, the second analog added) continuing from red tracks (containing IdU, the first analog added) or blue tracks (non-incorporated DNA) must be used to determine replication rate.

e. The length of the green track must be measured from intact green fibers: blue-green-red $(B G R)$, red-green-blue (RGB), and blue-green-red-green-blue (BGRGB) events.

36. Estimate the average replication rate using the formula:

$$
v=\frac{\left(\sum_{1}^{n} \text { lenght } / n\right)}{t}
$$

where $v$ is the average replication rate (in kb. $\mathrm{min}^{-1}$ ), $n$ is the number of DNA fibers analyzed, and $t$ is the time of CldU pulse (in min).

Note: At least three independent assays must be performed to improve the accuracy of the assay

\section{Data analysis}

1. With the possession of all variables (parameters) obtained previously, i.e., chromosome size, $S$-phase duration, and average replication rate, insert them in the formula and calculate the MO per chromosome analyzed.

$$
M O=\left\lceil\frac{N}{2 . v \cdot S}\right\rceil
$$

of note, $N$ is the size of the chromosome in question, $v$ is the average replication rate, and $S$ is the S-phase duration.

Note: If the right-hand side of the formula results in a fraction of a unit, then the next higher integer unit must be taken as the result of the formula, which is represented by the ceiling function ([ 1$)$. 
2. Prepare a table to add the MO values found and compare them with the number of replication origins estimated/mapped by other approaches (e.g., DNA combing, MFA-seq analysis). In the current protocol, Table 1 was prepared for T. brucei and Table 2 for S. cerevisiae, which were used to demonstrate that the MO estimation can be applied in any organism.

Table 1. Comparison among the MO, origins mapped by MFA-seq technique (Tiengwe et al., 2012), and origins estimated by DNA combing (Stanojcic et al., 2016) in T. brucei

\begin{tabular}{lcccc}
\hline $\begin{array}{l}\text { Chromosome } \\
\text { number }\end{array}$ & $\begin{array}{c}\text { Chromosome } \\
\text { Size (bp) }\end{array}$ & MO & $\begin{array}{c}\text { Origins mapped by } \\
\text { MFA-seq }\end{array}$ & $\begin{array}{c}\text { Origins estimated by } \\
\text { DNA combing }\end{array}$ \\
\hline I & $1,064,672$ & 3 & 2 & 7 \\
II & $1,193,948$ & 3 & 3 & 8 \\
III & $1,653,225$ & 4 & 3 & 11 \\
IV & $1,590,432$ & 4 & 3 & 10 \\
V & $1,802,303$ & 4 & 3 & 11 \\
VI & $1,618,915$ & 4 & 2 & 11 \\
VII & $2,205,233$ & 5 & 2 & 14 \\
VIII & $2,481,190$ & 5 & 6 & 16 \\
IX & $3,542,885$ & 7 & 4 & 20 \\
X & $4,144,375$ & 9 & 6 & 26 \\
XI & $5,223,313$ & 11 & 8 & 32 \\
\hline
\end{tabular}

S-phase duration $=138.6 \mathrm{~min}$ (da Silva et al., 2019), replication rate $=1.84 \mathrm{~kb} \cdot \mathrm{min}^{-1}$ (Stanojcic et al., 2016). The values presented in this table were originally published in (da Silva et al., 2019). 
Table 2. Comparison among the MO, known replication origins (Nieduszynski et al., 2006), and origins estimated by DNA combing (Lengronne et al., 2001) in S. cerevisiae

\begin{tabular}{|c|c|c|c|c|}
\hline $\begin{array}{l}\text { Chromosome } \\
\text { number }\end{array}$ & $\begin{array}{c}\text { Chromosome } \\
\text { Size (bp) }\end{array}$ & $\mathrm{MO}$ & $\begin{array}{c}\text { Known replication } \\
\text { origins }\end{array}$ & $\begin{array}{l}\text { Origins estimated by } \\
\text { DNA combing }\end{array}$ \\
\hline $\mathrm{I}$ & 230,218 & 3 & 12 & 6 \\
\hline II & 813,184 & 9 & 36 & 18 \\
\hline III & 316,620 & 4 & 15 & 7 \\
\hline IV & $1,531,933$ & 16 & 51 & 34 \\
\hline V & 576,874 & 7 & 17 & 13 \\
\hline $\mathrm{VI}$ & 270,161 & 3 & 14 & 6 \\
\hline VII & $1,090,940$ & 12 & 29 & 24 \\
\hline VIII & 562,643 & 6 & 20 & 13 \\
\hline IX & 439,888 & 5 & 14 & 10 \\
\hline$x$ & 745,751 & 8 & 27 & 17 \\
\hline$X I$ & 666,816 & 7 & 20 & 15 \\
\hline XII & $1,078,177$ & 12 & 31 & 24 \\
\hline XIII & 924,431 & 10 & 27 & 21 \\
\hline XIV & 784,333 & 9 & 21 & 18 \\
\hline$X V$ & $1,091,291$ & 12 & 27 & 24 \\
\hline$X V I$ & 948,066 & 10 & 24 & 21 \\
\hline
\end{tabular}

S-phase duration $=30$ min (Brewer et al., 1984; Ivanova et al., 2020), replication rate $=1.6$ $\mathrm{kb} \cdot \mathrm{min}^{-1}$ (Sekedat et al., 2010). The values presented in this table were originally published in (da Silva et al., 2020).

3. Set up a graph in order to show trend lines for each approach analyzed (Figure 3 was made for T. brucei and Figure 4 for S. cerevisiae). 


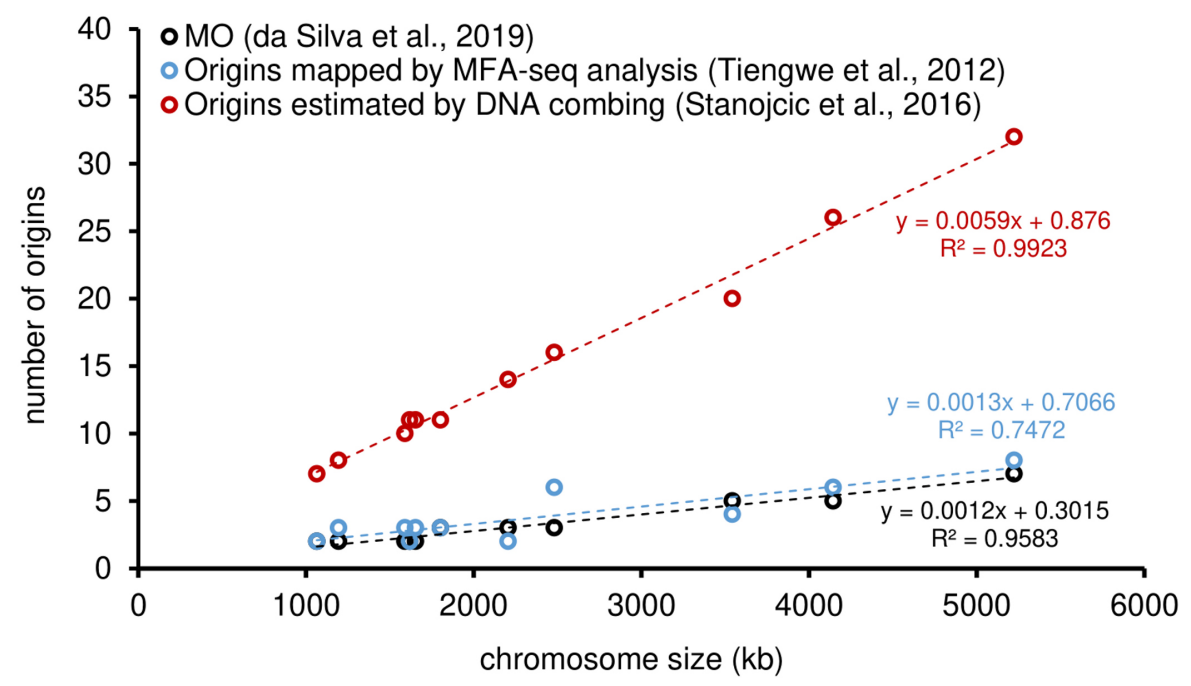

Figure 3. Comparative analysis among different approaches used to estimate origins in T. brucei. The graph shows positive correlations between chromosome size and the number of origins estimated by: MO (black), origins estimated by MFA-seq (blue), and origins estimated by DNA combing (red). The trend lines for the approaches, as well as the equations, are shown. Studies are referenced in the legend of the graph. The data presented in this graph were originally published in da Silva et al. (2019).

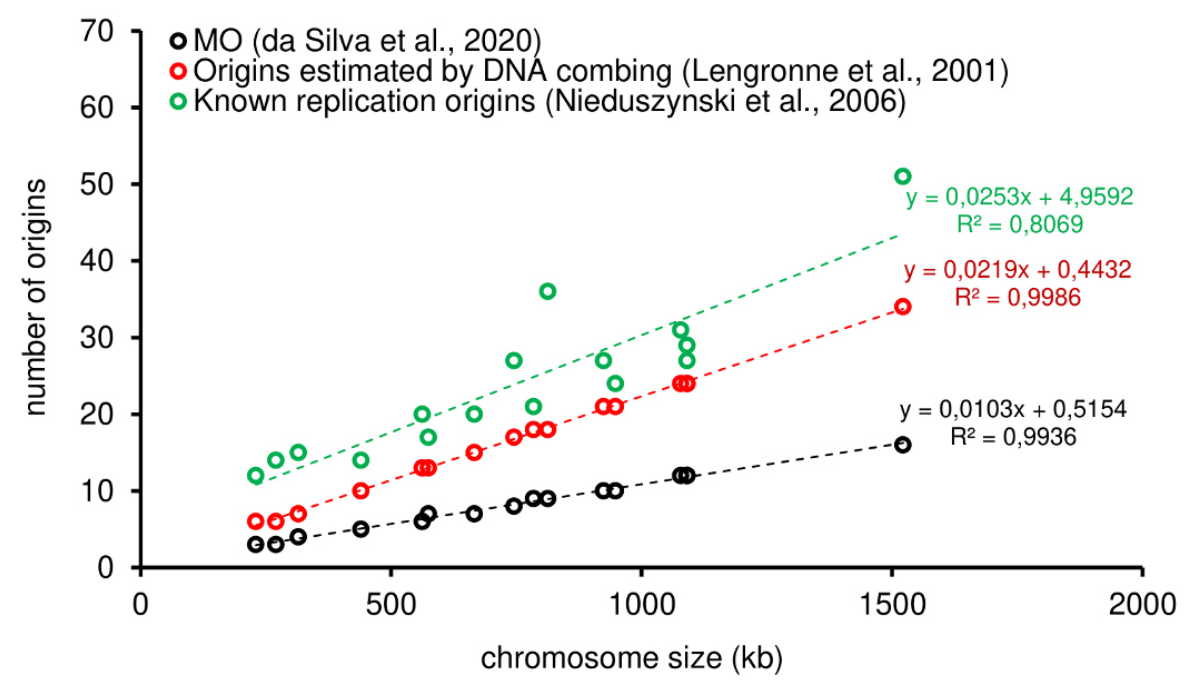

Figure 4. Comparative analysis among different approaches used to estimate origins in

S. cerevisiae. The graph shows positive correlations between chromosome size and the number of origins estimated by: MO (black), known replication origins (green), and origins estimated by DNA combing (red). The trend lines for the approaches, as well as the equations, are shown. Studies are referenced in the legend of the graph. The data presented in this graph were originally published in da Silva et al. (2020).

It is possible to observe an expected positive correlation between the number of origins and 
the size of each chromosome, i.e., the larger the chromosome, the more origins are required to replicate it within the S-phase duration. The MO allows the establishment of a threshold that can serve as a parameter by other methods. For instance, in T. brucei (Figure 3), when comparing the MO values with the MFA-seq ones, it is clear that some chromosomes are not able to be duplicated only with the origins mapped by MFA-seq, i.e., some blue circles are above from the threshold established by the MO values (black dotted line). Briefly, the reason is due MFA-seq approach has low resolution and map mainly constitutive (frequent) origins (da Silva et al., 2019 and 2020). Further analysis and a complete explanation can be found in the original publication from which this method was derived (da Silva et al., 2019).

\section{Notes}

A. General notes

1. If the values for the chromosomes size, S-phase duration, and replication rate are already available in the literature (i.e., they can be acquired from other studies), the Steps A-C described in 'procedure' are not necessary.

2. The number of DNA fibers $(n)$ analyzed in step c described on procedure must be as high as possible, since the higher the $n$, the more accurate the estimation of the replication rate will be.

B. Technical tips

1. To avoid false positives during the estimation of EdU-positive cells (Step B from procedure), do not overexpose fluorescence images during acquisition step.

2. The incubation time of the halogenated thymidine analogs (IdU and CldU) varies according to the doubling-time (Step $\mathrm{C}$ from procedure) and it can be optimized for other cell types. The same is valid for the incubation time of the EdU (EdU pulse) (Step B from procedure).

3. If it is possible, perform the whole protocol of DNA combing (Step $C$ from procedure) in the dark, because DNA with halogenated thymidine analogs incorporated is more sensitive to the light.

\section{$\underline{\text { Recipes }}$}

1. Phosphate buffered saline (1x PBS)

$137 \mathrm{mM} \mathrm{NaCl}$

\section{$2.7 \mathrm{mM} \mathrm{KCl}$}

$10 \mathrm{mM} \mathrm{Na}_{2} \mathrm{HPO}_{4}$

$2 \mathrm{mM} \mathrm{KH}_{2} \mathrm{PO}_{4}$

a. Prepare the buffer by adding $8 \mathrm{~g}$ of $\mathrm{NaCl}, 0.2 \mathrm{~g}$ of $\mathrm{KCl}, 1.44 \mathrm{~g}$ of $\mathrm{Na}_{2} \mathrm{HPO}_{4}$, and $0.24 \mathrm{~g}$ of $\mathrm{KH}_{2} \mathrm{PO}_{4}$ in $800 \mathrm{ml}$ of destilled water

b. Adjust the $\mathrm{pH}$ to 7.4 with $\mathrm{HCl}$

c. Complete the volume to $1 \mathrm{~L}$ with destilled water 
d. Dispense the solution into aliquots (e.g., $250 \mathrm{ml})$ and sterilize by autoclaving $\left(20 \mathrm{~min}, 120^{\circ} \mathrm{C}\right.$, liquid cycle)

e. Store at room temperature for up to six months

f. Check the $\mathrm{pH}$ after prolonged use

2. Hemin Solution (HS)

$50 \mathrm{mg} / \mathrm{ml} \mathrm{Hemin}$

a. Prepare the solution by adding $50 \mathrm{mg}$ of Hemin and $1 \mathrm{ml}$ of $1 \mathrm{M} \mathrm{NaOH}$ in $80 \mathrm{ml}$ of MilliQ water

b. Stir vigorously on a magnetic stirrer

c. Bring up the volume to $100 \mathrm{ml}$ with MilliQ water

d. Sterilize by filtering (using $0.22 \mu \mathrm{m}$ filter)

e. Store at $4{ }^{\circ} \mathrm{C}$ for up to one month

3. SDM-79 medium (for cultivate $T$. brucei procyclic cells)

$90 \%(\mathrm{v} / \mathrm{v})$ SDM-79 medium (incomplete)

$10 \%(v / v)$ heat-inactivated Fetal Bovine Serum (FBS)

$7.5 \mu \mathrm{g} / \mathrm{ml} \mathrm{Hemin}$

$0.134 \mu \mathrm{g} / \mathrm{ml}$ Streptomycin sulfate salt

$0.060 \mu \mathrm{g} / \mathrm{ml}$ Penicillin G sodium salt

a. Prepare the medium by adding $50 \mathrm{ml}$ of heat-inactivated FBS, $75 \mu \mathrm{l}$ of $\mathrm{HS}, 67 \mathrm{mg}$ of Streptomycin sulfate salt, and $30 \mathrm{mg}$ of Penicillin G sodium salt in $400 \mathrm{ml}$ of SDM-79 medium (incomplete)

b. Adjust the $\mathrm{pH}$ to 7.3 and complete the volume to $500 \mathrm{ml}$ with SDM-79 medium (incomplete)

c. Sterilize by filtering (using $0.22 \mu \mathrm{m}$ filter) and dispense into aliquots (e.g., $100 \mathrm{ml}$ )

d. Store at $4{ }^{\circ} \mathrm{C}$ for up to one month

4. 5'-chloro-2'-deoxyuridine solution (CldU-S)

$10 \mathrm{mM}$ of CldU diluted in water

a. Prepare the buffer by adding $26.26 \mathrm{mg}$ of 5'-chloro-2'-deoxyuridine in $9 \mathrm{ml}$ of water

b. Solubilizes and complete the volume to $10 \mathrm{ml}$

c. Sterilize by filtering (using $0.22 \mu \mathrm{m}$ syringe filter) and dispense the solution into aliquots (e.g., $1 \mathrm{ml}$ )

d. Store at $-20^{\circ} \mathrm{C}$ for up to six months

5. 5-ethynyl-2'-deoxyuridine solution (EdU-S)

$10 \mathrm{mM}$ of EdU diluted in 1x PBS

a. Prepare the solution by adding $2 \mathrm{ml}$ of $1 \mathrm{x}$ PBS to component A from Click-iT ${ }^{\circledR}$ EdU Imaging Kit

b. Mix well to solubilize it

c. Sterilize by filtering (using $0.22 \mu \mathrm{m}$ syringe filter) and dispense the solution into aliquots (e.g., $1 \mathrm{ml}$ )

d. Store at $-20^{\circ} \mathrm{C}$ for up to six months 
6. 5'-iodo-2'-deoxyuridine solution (IdU-S)

$10 \mathrm{mM}$ of IdU diluted in water alkalinized

Note: IdU is not readily soluble at physiological $\mathrm{pH}$.

a. Prepare the buffer by adding $35.4 \mathrm{mg}$ of 5'-iodo-2'-deoxyuridine in $5 \mathrm{ml}$ of alkalinized MilliQ water (adjust the Milli-Q water $\mathrm{pH}$ to 9.5 using $5 \mathrm{M} \mathrm{NaOH}$ with the aid of a pH meter)

b. Solubilize and complete the volume to $10 \mathrm{ml}$ with Milli-Q water

c. Sterilize by filtering (using $0.22 \mu \mathrm{m}$ syringe filter) and dispense the solution into aliquots (e.g., $1 \mathrm{ml})$

d. Store at $-20^{\circ} \mathrm{C}$ for up to six months

7. $0.5 \mathrm{M}$ EDTA, $\mathrm{pH} 8.0$

a. Prepare the solution by adding $186.1 \mathrm{~g}$ of disodium EDTA $2 \mathrm{H}_{2} \mathrm{O}$ to $800 \mathrm{ml}$ of distilled $\mathrm{H}_{2} \mathrm{O}$

b. Stir vigorously on a magnetic stirrer while adjust the $\mathrm{pH}$ to 8.0 with $\mathrm{NaOH}(\sim 20 \mathrm{~g}$ of $\mathrm{NaOH}$ pellets)

c. Bring up the volume to $1 \mathrm{~L}$ with distilled water

d. Dispense into aliquots (e.g., $250 \mathrm{ml}$ ) and sterilize by autoclaving

e. Store at room temperature for up to six months

8. $0.65 \mathrm{M}$ EDTA, $\mathrm{pH} 8.0$
a. Prepare the solution by adding $24.2 \mathrm{~g}$ of disodium EDTA $2 \mathrm{H}_{2} \mathrm{O}$ to $80 \mathrm{ml}$ of distilled $\mathrm{H}_{2} \mathrm{O}$
b. Stir vigorously on a magnetic stirrer while adjust the $\mathrm{pH}$ to 8.0 with $\mathrm{NaOH}$
c. Bring up the volume to $100 \mathrm{ml}$ with distilled water
d. Sterilize by autoclaving
e. Store at room temperature for up to one month

9. $1.5 \mathrm{M}$ Tris- $\mathrm{HCl}, \mathrm{pH} 8.8$

a. Prepare the solution by adding $181.65 \mathrm{~g}$ Tris base in $800 \mathrm{ml}$ of MilliQ water

b. Adjust the $\mathrm{pH}$ to 8.8 using concentrated $\mathrm{HCl}$

C. Bring up the volume to $1 \mathrm{~L}$ with MilliQ water

d. Dispense into aliquots (e.g., $250 \mathrm{ml}$ ) and sterilize by autoclaving

e. Store at room temperature for up to six months

10. $1 \mathrm{M} \mathrm{NaCl}$
a. Prepare the solution by adding $58.44 \mathrm{~g}$ of $\mathrm{NaCl}$ in $800 \mathrm{ml}$ of distilled $\mathrm{H}_{2} \mathrm{O}$
b. Stir vigorously on a magnetic stirrer (heat to help dissolve)
c. Bring up the volume to $1 \mathrm{~L}$ with distilled water
d. Dispense into aliquots (e.g., $250 \mathrm{ml}$ ) and sterilize by autoclaving
e. Store at room temperature for up to one year

11. $70 \%$ ethanol
a. Prepare the solution by adding $35 \mathrm{ml}$ of ethanol absolute in $15 \mathrm{ml}$ of distilled $\mathrm{H}_{2} \mathrm{O}$
b. Mix well and store at $4{ }^{\circ} \mathrm{C}$ for up to one year

12. $90 \%$ ethanol

a. Prepare the solution by adding $45 \mathrm{ml}$ of ethanol absolute in $5 \mathrm{ml}$ of distilled $\mathrm{H}_{2} \mathrm{O}$ 
b. Mix well and store at $4{ }^{\circ} \mathrm{C}$ for up to one year

13. DNA combing washing buffer (DC-WB)

100 mM EDTA, pH 8.0

$10 \mathrm{mM}$ Tris- $\mathrm{HCl}$

$20 \mathrm{mM} \mathrm{NaCl}$

a. Prepare the buffer by adding $20 \mathrm{ml}$ of $500 \mathrm{mM}$ EDTA, $666 \mu \mathrm{l}$ of Tris- $\mathrm{HCl}$, and $2 \mathrm{ml}$ of $\mathrm{NaCl}$ in $77.33 \mathrm{ml}$ of MilliQ water

b. Mix well and sterilize by filtering (using $0.22 \mu \mathrm{m}$ filter)

c. Store at $4{ }^{\circ} \mathrm{C}$ for up to one month

14. DNA combing lysis buffer (DC-LB)

0.65 EDTA, pH 8.0

$1 \% \mathrm{~N}$-Laurylsarcosine

$100 \mu \mathrm{g} / \mathrm{ml}$ Proteinase $\mathrm{K}$

a. Prepare the buffer by adding $50 \mu \mathrm{g}$ of $\mathrm{N}$-Laurylsarcosine and $500 \mu \mathrm{g}$ of proteinase $\mathrm{K}$ in $4 \mathrm{ml}$ of $0.65 \mathrm{M}$ EDTA, pH 8.0

b. Mix well and bring up the volume to $5 \mathrm{ml}$ using $0.65 \mathrm{M}$ EDTA, pH 8.0

c. Store at room temperature up to one week

15. DNA combing blocking solution (DC-BS)

1x PBS

$1 \%$ Bovine Serum Albumin (BSA)

$0.1 \%$ Triton X-100

a. Prepare the solution by adding $100 \mu \mathrm{g}$ of BSA and $10 \mu \mathrm{l}$ of Triton X-100 in $9,880 \mu \mathrm{l}$ of $1 \mathrm{x}$ PBS

b. Mix well and sterilize by filtering (using $0.22 \mu \mathrm{m}$ filter)

c. Store at $4{ }^{\circ} \mathrm{C}$ up to one week

16. DNA combing denaturation buffer (DC-DB)

\section{$0.5 \mathrm{M} \mathrm{NaOH}$}

\section{$1 \mathrm{M} \mathrm{NaCl}$}

a. Prepare the solution by adding $200 \mathrm{mg}$ of $\mathrm{NaOH}$ and $58.4 \mathrm{mg}$ of $\mathrm{NaCl}$ in $8 \mathrm{ml}$ of distilled $\mathrm{H}_{2} \mathrm{O}$

b. Mix well and bring up the volume to $10 \mathrm{ml}$ using distilled $\mathrm{H}_{2} \mathrm{O}$

c. Store at room temperature up to one week

17. DNA combing primary antibodies solution (DC-PAS)

$1 / 10$ anti-IdU (mouse anti-BrdU)

$1 / 10$ anti-CldU (rat anti-BrdU)

$100 \%$ DC-BS

a. Prepare the solution by adding $2 \mu \mathrm{l}$ of anti-IdU, $2 \mu \mathrm{l}$ of anti-CldU in $16 \mu \mathrm{l}$ of DC-BS

b. Mix well and use immediately

18. DNA combing secondary antibodies solution (DC-SAS) 
1/20 anti-mouse Alexafluor 568

$1 / 20$ anti-rat Alexafluor 488

$100 \%$ DC-BS

a. Prepare the solution by adding $1 \mu \mathrm{l}$ of anti-mouse Alexafluor $568,1 \mu \mathrm{l}$ of anti-rat Alexafluor 488 in $18 \mu$ l of DC-BS

b. Mix well and use immediately

19. DNA combing anti-ssDNA solution (DC-anti-ssDNA)

$1 / 5$ anti-ssDNA (mouse anti-ssDNA) $100 \%$ DC-BS

a. Prepare the solution by adding $4 \mu \mathrm{l}$ of anti-ssDNA in $16 \mu \mathrm{l}$ of DC-BS

b. Mix well and use immediately

20. DNA combing Alexafluor 350 (DC-alexa350)

$1 / 10$ anti-mouse Alexafluor 350

$100 \%$ DC-BS

a. Prepare the solution by adding $2 \mu \mathrm{l}$ of anti-mouse Alexafluor 350 in $18 \mu \mathrm{l}$ of DC-BS

b. Mix well and use immediately

21. $\mathrm{T}_{10} \mathrm{E}_{1}$ buffer

$10 \mathrm{mM}$ Tris- $\mathrm{HCl}, \mathrm{pH} 8.8$

1 mM EDTA, pH 8.0

a. Prepare the buffer by mixing $66.6 \mu \mathrm{l}$ of $1.5 \mathrm{M}$ Tris- $\mathrm{HCl}, 20 \mu \mathrm{l}$ of $0.5 \mathrm{M}$ EDTA, and 9,913 $\mu \mathrm{l}$ of MilliQ $\mathrm{H}_{2} \mathrm{O}$

b. Mix well and sterilize by filtering (using $0.22 \mu \mathrm{m}$ filter)

c. Store at $4{ }^{\circ} \mathrm{C}$ up to one month

22. $0.5 \mathrm{M}$ MES buffer, $\mathrm{pH} 5.5$
a. Prepare the solution by adding $9.76 \mathrm{~g}$ of MES free acid in $80 \mathrm{ml}$ of distilled $\mathrm{H}_{2} \mathrm{O}$
b. Stir vigorously on a magnetic stirrer
c. Adjust the $\mathrm{pH}$ to 5.5 using $\mathrm{NaOH}$
d. Bring up the volume to $100 \mathrm{ml}$ using distilled $\mathrm{H}_{2} \mathrm{O}$
e. Sterilize by autoclaving
f. Store at room temperature for up to one month

23. Fixation buffer (FB)

$4 \%(w / v)$ Paraformaldehyde in 1x PBS

a. Prepare the buffer by adding $2.1 \mathrm{~g}$ of Paraformaldehyde (powder, 95\%) in $40 \mathrm{ml}$ 1x PBS

b. Solubilize and complete the volume to $50 \mathrm{ml}$ with $1 \mathrm{x}$ PBS

c. Store at $4{ }^{\circ} \mathrm{C}$ for up to one month

24. Poly-L-lysine solution (PLS)

$0.1 \%(w / v)$ Poly-L-Lysine hydrochloride diluted in water

a. Prepare the buffer by adding $10 \mathrm{mg}$ of Poly-L-Lysine hydrochloride in $9 \mathrm{ml}$ of water

b. Solubilize and complete the volume to $10 \mathrm{ml}$ with water 
c. Sterilize by filtering (using $0.22 \mu \mathrm{m}$ syringe filter) and dispense the solution into aliquots (e.g., $1 \mathrm{ml})$

d. Store at $4{ }^{\circ} \mathrm{C}$ for up to six months

25. Permeabilization solution (PS)

$0.1 \%(v / v)$ Triton $\mathrm{X}-100$ diluted in $1 \times$ PBS

a. Prepare the buffer by adding $10 \mu \mathrm{l}$ of Triton X-100 in $9,990 \mu \mathrm{l}$ of $1 \mathrm{x}$ PBS

b. Mix well, sterilize by filtering (using $0.22 \mu \mathrm{m}$ syringe filter), and dispense the solution into aliquots (e.g., $1 \mathrm{ml})$

c. Store at $4{ }^{\circ} \mathrm{C}$ for up to six months

\section{Acknowledgments}

This work has been derived from da Silva et al. (2019) and da Silva et al. (2020). The development of the protocol presented here was supported by São Paulo Research Foundation (FAPESP) Center of Toxins, Immune Response and Cell Signaling (CeTICS) under grants 2014/24170-5 and 2017/18719-2. Currently, Marcelo S. da Silva is fellow from FAPESP (grants 2019/10753-2 and 2020/10277-3).

\section{Competing interests}

The author declares that there is no conflict of interest regarding the publication of this article.

\section{$\underline{\text { References }}$}

1. Brewer, B.J., Chlebowicz-Sledziewska, E., Fangman, W.L. (1984). Cell cycle phases in the unequal mother/daughter cell cycles of Saccharomyces cerevisiae. Mol Cell Biol 4: 2529-2531.

2. da Silva, M. S., Marin, P. A., Repolês, B. M., Elias, M. C. and Machado, C. R. (2018). Analysis of DNA Exchange Using Thymidine Analogs (ADExTA) in Trypanosoma cruzi. Bio-protocol 8(24): e3125.

3. da Silva, M. S., Cayres-Silva, G. R., Vitarelli, M. O., Marin, P. A., Hiraiwa, P. M., Araujo, C. B., Scholl, B. B., Avila, A. R., McCulloch, R., Reis, M. S. and Elias, M. C. (2019). Transcription activity contributes to the firing of non-constitutive origins in African trypanosomes helping to maintain robustness in S-phase duration. Sci Rep 9(1): 18512.

4. da Silva, M. S., Pavani, R. S., Damasceno, J. D., Marques, C. A., McCulloch, R., Tosi, L. R. O. and Elias, M. C. (2017). Nuclear DNA replication in trypanosomatids: There are no easy methods for solving difficult problems. Trends Parasitol 33(11): 858-874.

5. da Silva, M. S., Vitarelli, M. O., Souza, B. F. and Elias, M. C. (2020). Comparative analysis of the minimum number of replication origins in trypanosomatids and yeasts. Genes (Basel) 11(5).

6. Ishida, S., Huang, E., Zuzan, H., Spang, R., Leone, G., West, M., and Nevins, J. R. (2001). 
Please cite this article as: da Silva, (2020). Estimation of the Minimum Number of Replication Origins Per Chromosome in any Organism,Bio-protocol 10

Role for E2F in control of both DNA replication and mitotic functions as revealed from DNA microarray analysis. Mol Cell Biol 21(14): 4684-4699.

7. Ivanova, T., Maier, M., Missarova, A., Ziegler-Birling, C., Carey, L.B., Mendoza, M. (2020). Budding yeast complete DNA replication after chromosome segregation begins. Nat Commun 11(1): 2267.

8. Lengronne, A., Pasero, P., Bensimon, A., Schwob E. (2001). Monitoring S phase progression globally and locally using BrdU incorporation in $\mathrm{TK}^{+}$yeast strains. Nucleic Acids Res 2001, 29(7): 1433-1442.

9. Leonard, A. C. and Mechali, M. (2013). DNA replication origins. Cold Spring Harb Perspect Biol 5(10): a010116.

10. Mechali, M. (2010). Eukaryotic DNA replication origins: many choices for appropriate answers. Nat Rev Mol Cell Biol 11(10): 728-738.

11. Myllykallio, H., Lopez, P., Lopez-Garcia, P., Heilig, R., Saurin, W., Zivanovic, Y., Philippe, H. and Forterre, P. (2000). Bacterial mode of replication with eukaryotic-like machinery in a hyperthermophilic archaeon. Science 288(5474): 2212-2215.

12. Nieduszynski, C.A., Knox, Y., Donaldson, A.D. (2006). Genome-wide identification of replication origins in yeast by comparative genomics. Genes Dev 20(14): 1874-1879.

13. Pereira, P. D., Serra-Caetano, A., Cabrita, M., Bekman, E., Braga, J., Rino, J., Santus, R., Filipe, P. L., Sousa, A. E., and Ferreira, J. A. (2017). Quantification of cell cycle kinetics by EdU (5ethynyl-2'-deoxyuridine)-coupled-fluorescence-intensity analysis. Oncotarget 8(25): 4051440532.

14. Sekedat, M. D., Fenyö, D., Rogers, R. S., Tackett, A. J., Aitchison, J. D. and Chait, B. T. (2010). GINS motion reveals replication fork progression is remarkably uniform throughout the yeast genome. Mol Syst Biol 6: 353.

15. Stanojcic, S., Sollelis, L., Kuk, N., Crobu, L., Balard, Y., Schwob, E., Bastien, P., Pages, M. and Sterkers, Y. (2016). Single-molecule analysis of DNA replication reveals novel features in the divergent eukaryotes Leishmania and Trypanosoma brucei versus mammalian cells. Sci Rep 6: 23142.

16. Tiengwe, C., Marcello, L., Farr, H., Dickens, N., Kelly, S., Swiderski, M., Vaughan, D., Gull, K., Barry, J. D., Bell, S. D. and McCulloch, R. (2012). Genome-wide analysis reveals extensive functional interaction between DNA replication initiation and transcription in the genome of Trypanosoma brucei. Cell Rep 2(1): 185-197.

17. Zhang, Q., Bassetti, F., Gherardi, M. and Lagomarsino, M. C. (2017). Cell-to-cell variability and robustness in S-phase duration from genome replication kinetics. Nucleic Acids Res 45(14): 8190-8198. 